Religare, ISSN: 19826605, v.16, n.1, agosto de 2019, p.306-337.

\title{
Comunidade Gólgota: a cultura do rock como reflexo de uma "rebeldia com causa"
}

\author{
Global community: rock culture as a reflection of a "rebelling \\ with cause"
}

Maralice Maschio $^{1}$

\section{Resumo}

Temos por objetivo, através de compilações e aprofundamentos do terceiro capítulo da Tese de Doutorado em História, defendida pela UFPR, no ano de 2018, historicizar o percurso da Comunidade Gólgota no cenário religioso evangélico. Discutimos a origem da comunidade com a seguinte observação: a Gólgota pode não ter tamanho comparável a outras denominações religiosas pentecostais e neopentecostais, mas o traçado cultural chama a atenção. É o tônus da rebeldia como uma espécie de alma no trabalho de pesquisa e a Gólgota se desenhando como construção da linguagem, de metalinguagem. Qual rebeldia se quer? É possível se compreender mais do Brasil a partir das flâmulas do discurso conservador? Do problema da ideologia? Posteriormente, discutimos a organização da denominação religiosa problematizando seu projeto religioso, o espaço de culto, o estilo/estética, a noção de espetáculo nos rituais, percorrendo as relações entre o sagrado e o profano. Também pontuamos a origem histórica das práticas religiosas da comunidade, abordando seus ministérios e eventos. Observamos, também, o crescimento da comunidade pela rotatividade de público, percorrendo a questão central de que são poucos os que permanecem enquanto membresia. Desenvolvemos o raciocínio em dois momentos, explorando as táticas utilizadas pela Gólgota para atrair fiéis: 1) as ações missionárias e 2) o uso da mídia. Por fim, problematizamos quem entra e fica, explorando exemplos via entrevistas orais, através da trajetória religiosa de dois membros efetivos, os quais identificados com as propostas da comunidade Gólgota permaneceram, fortalecendo identidades e pertencimentos golgotanos.

\footnotetext{
${ }^{1}$ É Bacharelada e Licenciada em História (2005) e Mestre em História Social do Trabalho (2008) pela Universidade Estadual do Oeste do Paraná, Doutora em História pela Universidade Federal do Paraná (2018) e Pós Doutoranda em Religiosidades e Meio Ambiente pela Universidade Estadual de Ponta Grossa, vinculada ao Laboratório de Pesquisa em Memória, Cultura e Natureza. Professora QPM pela Secretaria de Educação do Paraná (SEED). Docente, Coordenadora de Ensino, Pesquisa e Extensão e uma das coordenadoras do Laboratório Multidisciplinar de Ensino, Pesquisa e Extensão da FAMA (Faculdade Municipal de Educação e Meio Ambiente de Clevelândia/PR). O presente texto registra agradecimentos à professora Dra. Roseli Boschilia, professor Dr. Fábio Augusto Scarpim e professor Dr. Ozias Paese Neves, imprescindíveis para concretização da Tese de Doutorado. E-mail: maralicemaschio@gmail.com
} 
Religare, ISSN: 19826605, v.16, n.1, agosto de 2019, p.306-337.

Palavras-chave: Igrejas Emergentes; Comunidade Gólgota; Juventude; Identidade; Pertencimento.

\section{Abstract}

We aim, through compilation and deepening of the third chapter of the $\mathrm{PhD}$ Thesis in History, defended by UFPR, in 2018, to historicize the path of the Golgotha Community in the evangelical religious scene. We discuss the origin of the community with the following observation: Golgotha may not be comparable in size to other Pentecostal and neopentecostal religious denominations, but the cultural layout draws attention. It is the tone of rebellion as a kind of soul in the research work and Golgotha drawing as a language construction, of metalanguage. What rebellion do you want? Is it possible to understand more about Brazil from the streamers of conservative discourse? From the problem of ideology? Subsequently, we discuss the organization of the religious denomination by problematizing its religious project, the space of worship, the style / aesthetics, the notion of spectacle in the rituals, covering the relations between the sacred and the profane. We also point out the historical origin of the community's religious practices by addressing their ministries and events. We have also observed the growth of the community through audience turnover, running through the central issue that few remain as members. We developed our thinking in two moments, exploring the tactics used by Golgotha to attract believers: 1) missionary actions and 2) the use of media. Finally, we question who enters and stays, exploring examples via oral interviews, through the religious trajectory of two effective members, who identified with the proposals of the Golgotha community remained, strengthening Golgotan identities and belonging.

Keywords: Emerging Churches; Golgotha Community; Youth; Identity; Belonging.

\section{Introdução}

Três são os pilares trabalhados pela Comunidade Gólgota: Salvação, Graça e Eternidade de Deus. A Salvação está em Jesus Cristo (se crer, a verdade libertará), a Graça (Deus deu a vida de graça para cada ser e Cristo morreu para redimir os pecados humanos) e a eternidade (preparada e determinada por Deus, cujo fiel deve crer também na Bíblia para alcançá-la). Discorreremos em torno dos dois momentos discursivos, nos quais se verifica o funcionamento dos

pilares: 1) na relação entre a Comunidade e o público-alvo (adeptos e 
Religare, ISSN: 19826605, v.16, n.1, agosto de 2019, p.306-337.

frequentadores); 2) na relação entre a denominação religiosa e o fiel pertencente (quando se torna membro efetivo).

A Comunidade Gólgota nasceu no ano de 2001, na cidade de Curitiba/PR, como dissidente da Comunidade Zadoque, denominação religiosa fundada em São Paulo, na década de 1990. De acordo com os discursos iniciais das lideranças, ela tinha o intuito de representar um espaço, com oferta de liberdade doutrinária e estilo visual com perfil juvenil. Na virada do século, a capital paranaense despontava, para os fundadores da comunidade, como uma cidade emergente no meio underground.

Volmir de Bastos (2010), que cresceu na Igreja Presbiteriana do Brasil, em Foz do Iguaçu/PR, na década de 80, abandonou a igreja para vivenciar uma experiência com o movimento punk. Era também guitarrista de uma banda de rock. A sua experiência com o estilo punk/rock é justificada como um motivo cultural para a sua existência religiosa. Experiência idêntica a do fundador da Comunidade Zadoque, Antonio Batista, da qual a Gólgota desmembrou.

Nesse sentido, aspectos da trajetória de vida e familiar do pastor aparecem atrelados às transformações socioculturais do movimento $p u n k^{2}$, vivenciadas nas décadas de 1980 e 1990, bem como as transformações religiosas no campo do Protestantismo/Pentecostalismo. A família de Bastos pertencia à protestante histórica Igreja Presbiteriana do Brasil. Sua mãe foi integrante da Pentecostal de segunda onda, em ascensão na época, a Igreja do Evangelho Quadrangular. O fato de a mãe ter deixado a Quadrangular por ter sido chamada de instrumento do diabo pelo presbítero revela uma questão teológica das igrejas pertencentes a tal matriz: a batalha de Deus contra o Diabo. Por sinal, tornou-se o elemento central para a profusão da terceira onda, o Neopentecostalismo, como é o caso da Igreja Universal do Reino de Deus.

\footnotetext{
${ }^{2}$ Teórica e metodologicamente as discussões de Joel Candau, em Memória e Identidade, de 2011 e de Zygmunt Bauman, em Identidade, de 2005, fundamentam essa abordagem que buscamos extrair da Tese de Doutorado, trazendo-a resumidamente para o presente texto.
} 
Religare, ISSN: 19826605, v.16, n.1, agosto de 2019, p.306-337.

A família do pastor golgotano também vivenciou experiência de trânsito religioso. Tal fenômeno acompanhou muitos evangélicos e, de certo modo, a própria sociedade brasileira, desde os anos 80. Paulo Romeiro (2005) argumenta que esse processo ocorreu porque os fiéis estavam "decepcionados com a graça" 3 .

Igreja emergente, como foi caracterizada a Comunidade Gólgota em seus primeiros anos, possui como característica central a conversão religiosa. Os líderes admitem colocar-se a serviço dos pecadores, dos excluídos da sociedade, das minorias, dos que não se encaixam em determinados padrões. Não apenas em discursos midiáticos, mas presenciais, observados durante a produção da pesquisa, a comunidade defende a premissa de que não pressiona os fiéis, de modo direto, à conversão; por sinal, premissa esta, existente desde o período da Reforma Protestante.

Por meio das mídias, também há discursos de fusão entre o que as lideranças denominam como cultura underground (do punk-rock) e o evangelho. A existência da comunidade é apresentada como um diferencial devido às questões culturais não impostas e, ao mesmo tempo, que compõe uma ética cristã, na fala do pastor: "Funcionamos como qualquer igreja neste mundo funciona". Assim, a fusão entre a cultura do rock e a proposta de evangelismo religioso são apresentados e representados como próprios dos sentidos de ser evangélico de sujeitos, que vivenciaram esse contexto secular brasileiro, entre as décadas de 1980 e 1990. Também funciona como "chamado", um convite para frequentar, não necessariamente pertencer.

Concernente à composição identitária da Comunidade Gólgota, em cultos presenciais e online, visualiza-se o local como um templo que parece uma garagem antiga, sem placa, um barracão rústico, todo pintado de preto. $\mathrm{O}$ altar é

\footnotetext{
${ }^{3}$ O livro do teólogo e historiador Paulo Romeiro (2005), que tem como título Decepcionados com a graça: esperanças e frustrações no Brasil neopentecostal, aborda as frustrações de muitos fiéis com o protestantismo histórico, uma vez que muitos líderes falam pela "graça" de Deus, mas não oferecem soluções para os problemas contemporâneos. Diferentemente, os neopentecostais passaram a oferecer soluções imediatas para um mundo aqui e agora, o que gera muito trânsito religioso entre evangélicos que estão em busca de esperança.
} 
Religare, ISSN: 19826605, v.16, n.1, agosto de 2019, p.306-337.

um palco, assemelhando-se a um show de rock secular. Os telões e as luzes completam o cenário. Nos fundos, há uma espécie de cozinha, onde são vendidos refrigerantes, água e acessórios como chaveiros, jaquetas, camisetas, cd's e dvd's de bandas.

Durante alguns cultos frequentados, observaram-se pregações do pastor abordando a juventude a partir do relacionamento entre pais e filhos. Inclusive, esta é uma questão que aponta mudanças ao longo da trajetória própria da comunidade. Inicialmente, pelo fato de se apresentar como uma igreja alternativa, emergente, no cenário evangélico, "de jovens falando para jovens" ela causou polêmica e, por vezes, conflitos com igrejas evangélicas mais tradicionais. Alguns pais chegaram a procurar às lideranças, preocupados com os filhos estarem frequentando os cultos. Tal experiência não é intrínseca à Gólgota. Outras igrejas e denominações religiosas vivenciaram a mesma situação e integrantes também relataram conflitos com os familiares ${ }^{4}$.

Estamos falando de uma movimentação. O participante, visitante quando é convidado a aceitar Jesus como seu único salvador integra um processo vivenciado por muitas igrejas evangélicas, de diferentes matrizes. Aceitar Jesus seria uma expressão religiosa que colocaria o sujeito em contato direto com a única entidade que pode salva-lo, redimir dos pecados, porque entregou a sua vida, morreu na cruz para a remissão humana. Tal dimensão estaria, inclusive, acima de qualquer bandeira de igreja, pois o contato de "aceitar Jesus" ocorre num selo, num pacto entre o indivíduo e Jesus Cristo, que se torna o único salvador e garantidor da vida eterna, embora intermediado pela liderança religiosa que convidará o participante a aceitar Jesus como seu salvador.

\footnotetext{
${ }^{4}$ Matérias sobre a Bola de Neve Church elucidam a questão: Bola de neve (2013). Disponível em: https://www.youtube.com/watch?v=Ue6vgSyxByk. Acesso em: 13 jun. 2018; da RPC sobre a Gólgota: Disponível em: https://www.youtube.com/watch?v=s4lqe0yEG9E. Acesso em: 13 jun. 2018, além de estudos na área de comunicação social como a Tese de Doutorado de Magali Cunha (2004), a dissertação de mestrado em História Social de Eduardo Meinberg Albuquerque Maranhão Filho (2013), estudos de antropologia como de Rafael da Silva Noleto (2016), entre outros.
} 
Religare, ISSN: 19826605, v.16, n.1, agosto de 2019, p.306-337.

Na Gólgota, por exemplo, aceitar Jesus como salvador implica contar com a graça de um Deus amoroso, expressa num pastor que age como um pai para o seu rebanho podendo, alguns frequentadores, tornarem-se adeptos da comunidade, movidos por um sentimento de acolhida. É o caso de alguns entrevistados. Entretanto, é preciso pontuar que, apesar da postura do pastor como pai (significado da lógica de pequenas comunidades de igrejas católicas também), que pode causar identificação e, talvez, ampliação do rebanho dentro da comunidade, há outras situações referentes ao possível crescimento ou não da comunidade, no decorrer do tempo, pois, conforme participação em shows promovidos pela Gólgota e nos cultos aos domingos o público frequentador é praticamente o mesmo.

Nos sábados há uma rotatividade maior de visitantes, que em sua maioria não a frequentam nos cultos de domingo, nem tampouco se tornam membros ativos. Vários jovens aparentam frequentar aos shows porque gostam do estilo musical e do visual do templo e dos integrantes. Eles são atraídos pela música, que muitas vezes não é sequer um rock cristão. Adotando práticas semelhantes à da Comunidade Zadoque, a Gólgota costumou abrir seu espaço para outras bandas curitibanas de rock secular aos sábados. Todavia, com a pesquisa etnográfica percebemos que, a partir de 2016, ela deixou de realizar shows seculares neste dia da semana.

A comunidade Gólgota também trabalha com uma categoria nativa: “o missionarismo prático". A proposta é a de preparar um missionário que conviva com as dores do mundo ao invés de afastar-se dele, como veremos adiante. Essa é uma postura divergente da grande maioria das igrejas protestantes e pentecostais de práticas mais tradicionais, sem contar que tal prática também lembra um tipo de missionarismo dos franciscanos: ajudam, são também filantrópicos, mas no fundo o objetivo parece ser o de trazer fiéis para sua comunidade. 
Religare, ISSN: 19826605, v.16, n.1, agosto de 2019, p.306-337.

\section{"O roqueiro, ele se achega neste lugar": a organização da comunidade gólgota e seu projeto religioso}

Desde 2001, é prática da Gólgota é a de reunir seus adeptos fiéis aos domingos. Às 18h00, vários jovens, atraídos pela música do rock e diferentes estilos representantes, louvam a Deus de um modo nada habitual. As luzes ficam acesas no barracão preto apenas no início e no final dos cultos, quando são apresentados os visitantes, durante a pregação e oração final. Há um tom de espetacularização no ritual, uma espécie de tentativa de causar a sensação de que o fiel está num show de rock, adaptado ao universo cristão, no sentido das letras das canções. O público parece representar uma espécie de espectador nos cultos, por parte da comunidade. Como disse o pastor Pipe, em entrevista à Revista RPC, afiliada da Rede Globo, em 2011, por tal estratégia “O roqueiro, ele se achega neste lugar" 5 !

É nessa desinterdição de áreas da mundanidade que os jovens evangélicos encontraram guarida nas últimas décadas ${ }^{6}$. Principalmente após anos 70, com os avanços comunicacionais, é que vimos um florescer dessa juventude religiosa enquanto organização religiosa, desde o Movimento de Jesus, a Mocidade para Cristo, os Atletas de Cristo, o Jovens como uma Missão, os engajamentos juvenis da Igreja Renascer em Cristo e da Bola de Neve Church, chegando até atuações juvenis em denominações religiosas como a Metanóia, a Zadoque e a Gólgota. Tais grupos passam a atuar no vazio, no espaço deixado pelas igrejas de práticas mais tradicionais. Possivelmente, podemos observá-los como lugares de segurança, em comunidades, diante de problemas familiares, doenças, vícios, falta de dinheiro, desemprego, dentre tantos aspectos que caracterizam o universo contemporâneo.

\footnotetext{
5 Matéria da Comunidade Gólgota na "Revista RPC" (2011). Disponível em: https://www.youtube.com/watch?v=s4lqe0yEG9E. Acesso em: 14 jun. 2018.

6 Sobre o tema ver mais: CARDOSO, Diogo da Silva. O rock e o metal a serviço de Deus: o lugar e os territórios do movimento underground cristão brasileiro. Anais do III encontro de geografia. Goyacazes-RJ: Instituto Federal Fluminense, 2010; e CATANI, Afrânio Mendes; GILIALI, Renato de Souza Porto. Culturas Juvenis: múltiplos olhares. São Paulo: Ed. UNESP, 2008.
} 
Religare, ISSN: 19826605, v.16, n.1, agosto de 2019, p.306-337.

A modernidade líquida ${ }^{7}$ parece caracterizar boa parte desses movimentos religiosos mais recentes. Por isso não se trata apenas de caracterizar a Gólgota como comunidade porque ela assim se apresenta, mas de dialogar com Zygmunt Bauman (2003) acerca de que a organização em comunidade parece representar a busca por segurança no mundo atual. No caso da Gólgota pode auxiliar no funcionamento de uma comunidade no sentido do refúgio, de representar um gueto dentro do gueto.

Tal contexto ajuda-nos a caracterizar o modo como a comunidade Gólgota se apresenta. Por intermédio de seus cultos, acompanhamos espetáculos estilísticos e estéticos, permanecendo o cunho cristão ou voltado a ele. Diante do metal cristão: música, religiosidade e performance na Gólgota, Patrícia Villar Branco (2011), produziu um trabalho situando a comunidade como inserida no campo religioso contemporâneo pós-movimento gospel. Tendo como suporte a mídia e a música, manteve suas práticas evangelizadoras baseadas na aceitação do universo secular ou de uma aproximação dele.

Branco (2011) ${ }^{8}$ designa a Gólgota com uma proposta de igreja emergente, que oferece uma liberdade de cultuar e viver a fé como o fruto de uma forma secularizada adequada à atualidade. É a liberdade de culto que propicia fenômenos performáticos no louvor golgotano, numa junção equilibrada entre o sagrado e o profano (um louvor brutal e agressivo do heavy metal adaptado a um discurso cristão de salvação, amor e cura pela aceitação de Jesus Cristo como Senhor), idêntico ao que promove a Comunidade Zadoque, em São Paulo.

\footnotetext{
${ }^{7}$ Na perspectiva de Zygmunt Bauman (1999), a revolucionada modernidade é líquida, efêmera e, por vezes, irreal. Em sua obra Modernidade Líquida, o filósofo polonês atribuiu à modernidade contemporânea, chamada pós-modernidade, a mesma plasticidade dos líquidos: leve, líquida e mais dinâmica que a modernidade sólida, transbordando, penetrando lugares, contornando o todo. Nela, o indivíduo também flui, ainda que podendo ser responsabilizado por suas ações e reações, visualizado como individualista, mais livre para questionar e refletir, reclamar e reivindicar.

8 Além da dissertação de mestrado de Branco (2011) sobre a Comunidade Gólgota, é possível consultar também o trabalho de conclusão de curso de Laís Cândida Ferreira: Geração que canta: As faces do rock na cultura evangélica juvenil brasileira (1990-2010). Curitiba: Departamento de História/UFPR, 2013.
} 
Religare, ISSN: 19826605, v.16, n.1, agosto de 2019, p.306-337.

Novamente, encontramos indícios da movimentação discursiva da comunidade, afinal este é o primeiro discurso utilizado, voltado para quem deseja integrar, e não, necessariamente, pertencer.

No sentido midiático, a primeira rede social que a Gólgota fez uso foi o Orkut, através de três comunidades, existentes entre os anos de 2006 a 2012: Comunidade Gólgota ${ }^{9}$ Descontradizendo Contradições ${ }^{10}$ e GolgotanosMotoClube ${ }^{11}$. Elas representam duas características da presença de comunidades evangelísticas na rede social ${ }^{12}$ : a organização de lideranças e, também, de membresia.

\footnotetext{
9 Servia para informar os horários de cultos e os shows, bem como funcionar como espaço para que os integrantes combinassem saídas (socialidade e sociabilidade) após as células e cultos.

${ }^{10} \mathrm{~A}$ comunidade Descontradizendo Contradições representa um Ministério da denominação religiosa. Transformou-se em Blog, em 2010, e em página do Facebook, em 2014, com link através do site oficial, seguindo a ideia da convergência midiática, como admite Henry Jenkins (2006). Os conteúdos são transferidos de uma rede a outra, conforme transformação da área comunicacional e tentativa de acompanhá-la. É como se qualquer religião que atualmente pretenda existir, seja ela tradicional ou nova, precise estar na mídia. Foi o que reconheceu Stewart Hoover (2006), ao admitir a possibilidade de se observar o campo evangélico como a expressão de cultura midiática de grupos.

${ }^{11}$ A comunidade do Orkut GolgotanosMotoClube também representa um ministério com conteúdo transferido para a página do Facebook, em 2014. Ela representava a identidade cultural especialmente de roqueiros, motoqueiros, cabeludos, tatuados com faixa etária entre 20 e 25 anos, que ajudaram na fundação da Gólgota. Em sua maioria, eles evidenciam um grupo juvenil não apenas caracterizado por idade, mas por geração, que está envelhecendo com a denominação religiosa, mantendo seu estilo e estética culturais. No entanto, a comunidade e o Ministério funcionam de modo interdependente, recebendo apoio institucional. Conforme os dizeres do líder do MotoClube, "a comunidade do Orkut contava com um número pequeno de participantes, porém, com constantes convites sobre torneios e encontros de moto em Curitiba e demais cidades brasileiras, nem sempre com conteúdos cristãos declarados" (LUCAS, 2010).

${ }^{12}$ Não apenas por uma questão de apresentação e comprovação de dado, mas por um lado histórico de que, talvez, em breve tempo, dependendo da geração, muitas pessoas nem saberão o que é ou foi, a ferramenta Orkut foi criado em 2002 e extinto em 30 de setembro de 2014, substituído pelo Facebook, mundialmente. Ver mais características sobre a plataforma em História do Orkut. Disponível em: http://www.techtudo.com.br/noticias/noticia/2014/07/historia-doorkut.html. Acesso em: 20 jun. 2018.
} 
Religare, ISSN: 19826605, v.16, n.1, agosto de 2019, p.306-337.

O Site Oficial da Gólgota foi criado em 2001, mas apresentou alteração de plataforma significativa somente em 2010. A alteração serve como exemplo e, também, hipótese de que existe uma tentativa institucional de redirecionamento no que se refere ao público, assim como há dinâmicas dos próprios meios disponíveis na Internet. Nesse momento, a denominação parece novamente competir com outras igrejas e vertentes do campo, como a Bola de Neve Church, em Curitiba, que promoveram alterações nas plataformas digitais no mesmo período. 
Religare, ISSN: 19826605, v.16, n.1, agosto de 2019, p.306-337.

O que nos chamou atenção foi como a Gólgota explicita seus ministérios missionais ${ }^{13}$, suas atuações dentro e fora dos templos, dentro e fora das mídias. O site oficial apresentou os seguintes ministérios entre os anos de 2008 e 2010: Ação Social ${ }^{14}$, Descontradizendo Contradições ${ }^{15}$, Evento GolgotanosMotoClube ${ }^{16}$, Intercessão ${ }^{17}$, Golgoteens ${ }^{18}$, Infantil ${ }^{19}$, MetalCast ${ }^{20}$ e Shows $^{21}$.

No ano de 2015, manteve-se o site no mesmo formato tecnológico. Entretanto, foram suprimidos dois temas, presentes na aba Ministério: o

${ }^{13}$ De modo geral, há a ideia, no campo do Protestantismo/Pentecostalismo, de que Ministérios estão ligados aos Pastores ou Ministros da Igreja. Para a grande maioria dos evangélicos, essa definição trata apenas da estrutura institucional ministerial. Biblicamente, "atenta para o Ministério que recebeste no Senhor, para que o cumpras" (Colossenses 4:17). Ou seja, a Bíblia preserva o significado de Ministério como a "execução de uma tarefa", relacionadas às passagens referentes ao sentido de que qualquer fiel pode e deve cumprir seu ministério até a vinda de Cristo, para que herde a salvação final (Projeto Gospel: o que significa o ministério. Disponível em: https://projetogospel.com/o-que-significa-ministerio/. Acesso em: 8 jul. 2018. Talvez seja nesse sentido que se situe a proposta da Gólgota de promover missionarismo onde quer que o fiel esteja, alicerçados às propostas ministeriais, conforme os dons de cada um. Aparentemente, os Ministérios são voltados ao mundo e não à Igreja. Em alguns momentos, chegam a denotar um sentido laico, próximo do social. Alguns entrevistados até comentaram que, se Jesus estivesse aqui, ele não estaria andando no meio das pessoas certinhas, e sim dos perdidos e excluídos. Aliás, tal argumento não é exclusivo da Gólgota, outras denominações religiosas como a Bola de Neve Church também apresentam.

${ }^{14} \mathrm{O}$ Ministério de Ação Social tem como objetivo a preocupação com o semelhante. É direcionado primeiramente aos membros, mas se estende à comunidade em geral, com o intuito de demonstrar o amor de Cristo para com o sujeito, incentivando a misericórdia que ele espera de uns para com os outros. Campanhas de doação incentivam os membros a participarem dos movimentos solidários de arrecadação de alimentos, não incluído verba financeira para tal finalidade. O incentivo se dá por meio de dizeres como: "muitas vezes, quando estamos bem, passamos a não acreditar que infortúnios nos assolarão, tirando o pão da nossa mesa, causando desespero, desesperança, tristeza e solidão".

${ }^{15} \mathrm{O}$ Ministério Descontradizendo Contradições, liderado pelo pastor, tem por objetivo oferecer informações aos jovens cristãos e não cristãos, que provavelmente não possuem acesso a materiais apologéticos: "o propósito é dar suporte a estes e ser uma ferramenta nas mãos de Deus para a conversão dos que não creem. Pois muitos tem tido sua fé abalada por não ter respostas aos incessantes ataques ateístas".

${ }^{16} \mathrm{O}$ GolgotanosMotoClube é um Ministério formado por membros da Comunidade Cristã underground de Curitiba, funcionando de modo independente, ou seja, nem sempre mencionado como comunidade cristã. Ele se direciona "para a galera que curte motociclismo, vento no rosto, total liberdade e muito rock' and'roll, com o objetivo de estarmos unidos como uma grande família".

${ }^{17} \mathrm{O}$ Ministério de Intercessão é um dos mais valorizados pela instituição religiosa, ocupando inclusive parte importante e considerável dos cultos aos domingos. Quando fazem orações para os participantes que se encontram com problemas, estes se dispõem a ir ao púlpito para que os obreiros orem por eles, conforme observado durante trabalho de campo. Tratando-se da escolha dos líderes do Ministério, existe um ritual de separação, tendo restrições para quem deseje participar do referido ministério. 
Religare, ISSN: 19826605, v.16, n.1, agosto de 2019, p.306-337.

Golgoteens e o Shows. Sugerimos algumas hipóteses para essa exclusão: no que se refere ao Golgoteens, a denominação religiosa parece não contar com um público adolescente como membresia, apesar dos esforços realizados pela Comunidade para alcançá-los. No que se refere aos shows, embora a atividade não seja mais mencionada no portal, ela não deixou de ser realizada, afinal é uma das principais características e estratégias missionárias da denominação religiosa desde os primeiros anos. Ela foi incorporada ao Ministério Eventos ${ }^{22}$. A comunidade hibridiza aspectos tradicionais e modernos, sagrado e profano, mesmo dentro das ferramentas tecnológicas disponíveis em cada momento histórico de criação e propagação. Esse fator, de certo modo, alicerça parte da discussão que buscamos fundamentada na Tese de Doutorado com Michel de Certeau, em A Invenção do Cotidiano - Artes do Fazer, de 1998, para historicizar a

\footnotetext{
${ }^{18} \mathrm{O}$ recente e já extinto Golgoteens foi um ministério que recebeu atenção detalhada no site, durante os seus anos de funcionamento, possivelmente para despertar a atenção de um novo público. Formado por um grupo pequeno de adolescentes da própria Comunidade, entre 12 e 18 anos, tinha por objetivo o discipulado, aconselhamento, ensinamento da palavra, tempo de comunhão, evangelismo. As reuniões do último sábado de cada mês seguem o louvor, espaço para os adolescentes desabafarem e compartilharem a sua história, dízimos e ofertas, dinâmica ou atividade recreativa, ministração da palavra, pedido de oração, lanche e informações. Os aconselhamentos individuais são feitos depois do horário do encontro. Promove ainda uma reunião especial chamada Acampadentro, realizado no salão dos cultos da Gólgota, duas a três vezes por ano, onde os adolescentes tem tempo maior de administração, diversão, comunhão, oração, palavra sempre com toda segurança e supervisão dos líderes.

${ }^{19} \mathrm{O}$ Ministério Infantil é responsável pela evangelização e alfabetização cristã das crianças, que frequentam a Comunidade Gólgota. Ele funciona como uma espécie de classe de ensino, com estrutura parecida das escolinhas dominicais, durante os cultos, aos domingos. Conta com algumas atividades recreativas no estacionamento para motos da denominação religiosa. Os conteúdos ensinados são histórias bíblicas, como ter uma vida junto com Cristo e diversos preceitos cristãos numa linguagem adequada para a criança.

${ }^{20} \mathrm{O}$ Ministério MetalCast foi criado para cuidar de conteúdos online da comunidade como sites, pregações em áudio e transmissão ao vivo de cultos. Atualmente, também dispõe de aplicativo para celulares, desenvolvido em 2018, com todo o acervo produzido pela comunidade e sobre ela, ao acesso do internauta. Para visitar o site, ouvir e baixar músicas, mensagens e pregações, basta acessar o link.

${ }^{21} \mathrm{O}$ Ministério de Shows, liderado pelo pastor, e tem por objetivo o evangelismo através de shows dentro da Gólgota. Há uma equipe que trabalha na organização e, ao mesmo tempo, foca no evangelismo do público. As bandas são todas bem-vindas independente da crença e religião, pois para alcançar as pessoas que não conhecem Jesus Cristo, precisamos andar com elas.

${ }_{22}^{2}$ Todos os Ministérios descritos a seguir podem ser consultados no site da Comunidade Gólgota. Disponível em: http://www.comunidade.golgota.org/. Acesso em: 13 out. 2015.
} 
Religare, ISSN: 19826605, v.16, n.1, agosto de 2019, p.306-337.

Comunidade Gólgota como um exemplo do campo evangélico contemporâneo a partir de suas concepções e práticas, estratégias e táticas.

Outro dado que merece atenção é a organização da Gólgota pelo número de eventos, dentro e fora de seus templos, observados conforme percorremos seu ciberespaço. Entre 2011 e 2012, a página do Facebook Eventos esteve praticamente inoperante. Ela contava com fotos de cultos, músicas de bandas gospel e algumas passagens bíblicas, mas, a partir da sua intensificação de uso, em 2013, observamos um mesmo formato estratégico até dezembro de 2015.

Tendo em vista a nossa metodologia de observar, arquivar e analisar o ciberespaço institucional, a distribuição de todas as postagens produzidas pela denominação religiosa desde sua origem, 2011 até 2015 foi organizada por temas encontrados: eventos ${ }^{23}$, projetos de formação ${ }^{24}$, projetos sociais $^{25}$, educação cristã ${ }^{26}$

\footnotetext{
${ }^{23}$ Os eventos anunciados pela Gólgota foram: bazares, batismo, campanhas do agasalho e de Páscoa do Ministério Golgotano, MotoClube, shows de bandas na denominação religiosa e em Curitiba, shows de lançamentos de CD's de bandas de rock gospel, cantatas, festas temáticas (festa do horror, festa do contra, festa a fantasia, retro a gogo, festas comemorativas de aniversário de ministérios e da comunidade), festivais (GólgotaFest, Powerprise, Outono Hardcore), piqueniques em parques de Curitiba, congresso de arte (Primeiro Coliseu: o cristão e a arte) e treinamento para evangelismo de prostitutas e travestis.

${ }^{24}$ Os projetos de formação foram observados linearmente em: treinamento para participar do Ministério MotoClube, convites para o batismo e rock'and'roll, treinamento em passo a passo do pastor Pipe sobre peregrinações (disponível no MetalCast), treinamento do pastor sobre escatologia nos evangelhos, pregações temáticas (antiCristo, questões existenciais, ateísmo, sexualidade), fórum sobre doutrina da predestinação, treinamento para evangelismo de prostitutas e travestis.

${ }^{25}$ Os projetos sociais foram: bazar de roupas para ajudar moradores de rua, shows cujas entradas são alimentos não perecíveis para doações às instituições de caridade, festa MotoCulto com arrecadação de agasalhos para doações, Páscoa dos Golgotanos com arrecadação de chocolate para crianças carentes.

${ }^{26} \mathrm{~A}$ Educação Cristã foi dividida em: postagens com passagens bíblicas, mensagens religiosas a partir de vídeos no Canal III Minutos e pregações do pastor, trechos de livros de autores como: C. S. Lewis, São Tomás de Aquino, Santo Agostinho, René Kivitz, Thomás Brooks, Rick Warren, Billy Graham, Max Lucado, G. K. Chesterton, S. D. Gordon, Jown Scott, Hellen Kaler e Augusto Cury.
} 
Religare, ISSN: 19826605, v.16, n.1, agosto de 2019, p.306-337.

e demais assuntos ${ }^{27}$, conforme eles apareceram, cronologicamente, na linha do tempo da página da Comunidade ${ }^{28}$.

Foi possível concluir que a Gólgota manteve, ao longo dos anos, apenas as estratégias e táticas que produziram identificação e repercussão entre os fiéis, sendo enfatizadas temáticas, em sua maioria, dentro da própria comunidade, ao invés de via redes sociais. A identidade e o pertencimento dos golgotanos aparecem direcionados, inclusive no sentido do entretenimento, cada vez mais por aspectos da cultura gospel contemporânea (e os modos de vida jovem, especialmente via estilo musical e estético: a música rock, o estilo e as práticas do motociclismo e o estilo visual do punk rock, visíveis no culto, passeios e shows realizados). Já a ênfase na difusão da mensagem religiosa é ajustada, nos últimos anos, para pequenos trechos bíblicos, diferentemente dos primeiros anos.

\section{Encarando a cidade como missão: "seja missionário onde você estiver!"}

Entre o público underground, os punks e os motoqueiros recebem lugar de destaque na Gólgota, visto que estilo/estéticas visuais e musicais representaram as principais tentativas de identificação com os grupos, caracterizando identidades e pertencimentos desde a fundação da comunidade. No que se refere

\footnotetext{
${ }^{27} \mathrm{Os}$ demais assuntos das páginas foram divididos em: fotos de eventos de cultos, links para assistir aos cultos pelo Livestream via Twitter, convites para acessar canais do YouTube(ComunidadeGólgota, Pipedesertor, Canal III minutos), indicação de atualizações/alterações do site, convite para leitura de matérias do pastor Pipe no Blog Descontradizendo Contradições, venda de camisetas, CDs e DVDs de bandas de rock gospel.

${ }^{28}$ Traçamos uma espécie de métrica dos dados analisados, observando diminuições no número de postagens entre os anos de 2013 e 2015. De 45 eventos em 2013, passou de 29 em 2014 para 25 em 2015. De 5 projetos de formação, em 2013, diminuiu para nenhum em 2014, crescendo para 2 em 2015. Dos projetos sociais registrados em 2013, caiu para nenhum, em 2014, e permaneceu com nenhum em 2015. Dos indicativos de educação cristã, em 2013, houve redução para 30, em 2014, e para 17, em 2015. Dos demais assuntos, de 73 em 2013, caiu para 3 em 2014 e nenhum em 2015. Uma vez que a Comunidade Gólgota criou um ministério específico para cuidar das mídias institucionais, em 2010, não se trata apenas de observar decréscimos de números para caracterizar a sua movimentação. As plataformas apareceram menos poluídas, acompanhando a área de WebDesign, o que implica, talvez, apenas na diminuição das chamadas e informativos para explicitar as estratégias e táticas utilizadas, diferentemente dos primeiros anos de utilização das páginas oficiais do Facebook.
} 
Religare, ISSN: 19826605, v.16, n.1, agosto de 2019, p.306-337.

aos punks, a principal estratégia parece ser a de construir um universo ressignificado culturalmente, com estilo/estética mantidos, mas afastado da agressividade, do envolvimento com drogas e rebeldia - comportamentos intrínsecos ao próprio movimento: "a cultura do rock como reflexo de uma rebeldia com causa".

O pastor Volmir de Bastos, o Pipe como é conhecido, comenta que foi a partir da sua experiência com os punks que surgiu a necessidade de trabalhar com o movimento, pensando em uma proposta de ação missionária.

Desde que eu fui punk uma das coisas do movimento é que na filosofia não pode fazer o uso de drogas, ele não poderia fazer uso de drogas também, porque o movimento punk se assemelha um pouco com o cristianismo, só que na praticidade a gente vê que não é isso. É um movimento muito hipócrita, ele propõe a não violência e tão brigando na rua! Propõe uma vida de liberdade, mas os caras são viciados em cocaína, crack, maconha, entendeu? Tão presos! Essa foi uma das coisas que me empurram por definitivo para o cristianismo, porque eu já vinha de uma série de desilusões quando olhava pros meus amigos. Na prática a coisa era diferente. Nos encontros revolucionários no Brasil, os punks chegavam lá e chutavam latas de lixo. Eu falava assim pros caras: peraí, mas quem você acha que vai juntar esse lixo ai? Você acha que é algum militar? Porque era contra os militares que a gente protestava! Quem vai juntar isso daí é um gari, um coitado de desses aí trabalhando, cara! E também pelo fato de eu ter sido criado no evangelho, o movimento punk ele é contrário a todo tipo de religião, a Deus, ao cristianismo, e eu não podia virar ateu como eles. E sempre que você levantava a questão dentro de uma reunião, assim, com relação à fé cristã eu era excomungado! Então desde que eu me converti, com uma semana de conversão lá em Foz do Iguaçu Deus já me deu um chamado evangelista e eu comecei ir pras praças pregar o evangelho, principalmente pros punk, tanto que eu comecei a ter atrito com a Presbiteriana porque eu comecei a levar os punks pra dentro da Igreja. Então desde lá e na Gólgota, de forma mais intensa, nós temos uma missão com os punks! (BASTOS, 2010).

O discurso de Pipe apresenta-se com certo descompasso. Ao mesmo tempo em que, inicialmente, ele apresenta o movimento punk como filosofia semelhante ao cristianismo, na sequência, argumenta que sua saída do movimento se deu pelo fato de que os membros são em sua maioria ateus, não 
Religare, ISSN: 19826605, v.16, n.1, agosto de 2019, p.306-337.

aceitando expressões de fé. Alicerça, ainda, o seu argumento com uma crítica de que o movimento é hipócrita ao não cumprir suas próprias premissas. Por outro lado, faz questão de frisar que, desde o momento em que iniciou o processo de evangelização, conseguiu levar vários punks para o evangelho. Outro ponto interessante é a menção de que, naquele momento, frequentava a Igreja Presbiteriana, com posturas tradicionais, cujos líderes não viram com bons olhos a sua atitude missionária de conduzir os punks ao templo. No entanto, no que se refere à Gólgota, fica a evidência de que o que permanece do punk é apenas o estilo/estética.

Dito isso, a postura da denominação religiosa também parece ser tradicional, apesar da crítica: ou o sujeito abandona boa parte de suas práticas ou não será aceito na Comunidade. Aqui entra em cena o terceiro passo dos pilares golgotanos: a eternidade de Deus. Para que se herde o reino, é preciso mudar o comportamento, seguir uma doutrina e aceitar as normas institucionais.

Durante o ano de 2012 conforme observamos a movimentação midiática da Comunidade Gólgota, especialmente no mês de maio o chamado "missionarismo prático" voltou-se para questões relacionadas ao aborto, à prostituição e à homossexualidade. Conhecer a cidade, o mundo e como as pessoas enxergam e vivenciam essas experiências apresentou-se como um dos motivos centrais para que a comunidade desenvolvesse seus projetos, justificados na utilização de qualquer espaço onde o golgotano esteja, não apenas o espaço do templo, para fazer "missão": o estúdio de piercing e tatuagem, de dois líderes religiosos, por exemplo. Esses projetos, exceto os sociais como Campanha do Agasalho, Páscoa, Natal e Treinamento para Tratar de Prostitutas e Travestis nas Ruas não aparecem mencionados nas plataformas midiáticas com grande frequência. No entanto, especialmente no Twitter o informativo de que está acontecendo treinamentos para prostitutas, travestis e homossexuais na Gólgota aparece, mas sem detalhamento. Nas entrevistas orais, ao contrário, eles são mencionados por vários integrantes como formas de "levar os ensinamentos 
Religare, ISSN: 19826605, v.16, n.1, agosto de 2019, p.306-337.

de Cristo para as pessoas" e de "conduzir as pessoas para a comunidade de Cristo".

O contexto pontuado acima foi o que nos levou a escolha das fontes discutidas na sequência do texto, principalmente as que trataram, no ano de 2012, sobre prostituição e homossexualidade. O missionarismo prático também apareceu como preparação do missionário para lidar com as vivências envolvendo suas atividades. Por sinal, os cursos de treinamento para lideranças foram os que encontramos abordando as polêmicas, que estavam aparecendo na sociedade brasileira como um todo, naquele momento, bem como utilizados pela comunidade gólgota em forma de estratégia para arrebanhar fieis, por intermédio de práticas como as referidas.

Os projetos são denominados pelas lideranças como projetos de missionarismo prático, de desafio, ensinamento e cura. É a filantropia em ação. A cultura pode ser o canal de identificação, alteridade, pertencimento, compartilhamento e ensinamento para um mundo que se pretenda cristão. Há indícios para a atuação missionária da Gólgota não apenas como assistencialismo social, mas como reabilitadora. Os integrantes enxergam a prostituição, a dependência química e a homossexualidade como desvios de caráter decorrentes dos próprios vícios que o sujeito desenvolve e, por isso, parte dos objetivos a serem promovidos pelo missionarismo prático. Não é à toa, dentro da comunidade, a participação e, consequente, extensão prática de missionários que são pedagogos, psicopedagogos e psicólogos, que utilizam suas áreas de formação como prática missionária dentro e fora da comunidade, bem como há formação para tais áreas nos Seminários Teológicos, em escala global. Indicativo disso está especialmente nas práticas da comunidade, desde 2012, no tratamento da comunidade LGBT, de prostitutas e de travestis.

Consequentemente, selecionamos para a discussão um Seminário promovido na Gólgota, disponível no MetalCast, intitulado “Sexo na Igreja: 
Religare, ISSN: 19826605, v.16, n.1, agosto de 2019, p.306-337.

Santo ou Profano?", de 5 de maio de 2012, ministrado por Karla ${ }^{29}$. O fato de ela ser psicóloga influencia diretamente na sua fala como representante da comunidade. Assim, imaginamos que seria quase "natural" assumir um discurso de não condenação a uma sexualidade mais livre. Karla fala do contexto da sociedade brasileira como a maior justificativa e, consequentemente, a necessidade de as denominações religiosas não terem vergonha de tocar em temas polêmicos como o sexo e a sexualidade. Não esquecendo que os argumentos da psicóloga, na verdade, o próprio seminário da Gólgota, faz parte de um momento da política brasileira, de 2012, o de debates sobre a criminalização da homofobia.

Todo ser humano tem direito de exercer a sua sexualidade da forma como quer. Existem leis hoje, a lei da homofobia que tá sendo discutida muito e agora dia 15 de maio volta em audiência para discutir inclusive questões da fé cristã. De falar o que a gente pensa, o que a gente opina com relação à homossexualidade. Para nós é uma opinião cristã, embasada na bíblia. Amém? Fora isso a gente tem que entender que todo mundo pode exercer a homossexualidade, a bissexualidade, o que quiser e a gente tem que respeitar, a questão é respeitar! É que hoje a gente vê uma sociedade pós-moderna em que a gente pode experimentar de tudo, que tudo é liberado, eu posso ter um relacionamento heterossexual, amanhã eu posso ter um relacionamento homossexual, depois eu posso definir que eu sou bi, depois eu posso fazer suingue, troca de casal, sexo grupal, tudo é liberado na nossa sociedade hoje. Em contrapartida a gente vê uma igreja que reprime, que não fala sobre o sexo, que não se posiciona. Então o mundo tá liberadíssimo e a igreja ainda fechada ${ }^{30}$ (Grifos meus).

Karla se refere à sociedade pós-moderna como liberal demais, pois atrai as pessoas, fazendo-as acreditar que tudo é permitido. O cenário é o de um mundo liberal e de igrejas e denominações religiosas fechadas. Por outro lado, independente de crença ou doutrina, a psicóloga fala da necessidade do respeito, reconhecendo a importância da criação da Lei de criminalização da homofobia,

\footnotetext{
${ }^{29}$ Apesar dos discursos estarem disponíveis no portal da Comunidade Gólgota, optamos pela utilização de nomes fictícios.

${ }_{30}$ Comunidade Gólgota. Disponível em: https://www.comunidade.golgota.org. Acesso em: 20 jan. 2018. Grifos meus.
} 
Religare, ISSN: 19826605, v.16, n.1, agosto de 2019, p.306-337.

por exemplo. Trata-se de uma separação entre as leis dos homens e as leis de Deus em que a psicóloga está apresentando dois saberes: o religioso e o científico, de forma confluente. Além disso, vemos novamente a questão dos pilares golgotanos, referente à graça, ao amor de Deus e a Cristo que morreu pelos pecados humanos. Basta reconhecer e assumir o pecado que obterá piedade e perdão. No caso dos homossexuais, estando disposto a abandonar a prática, obterão também a cura.

No discurso de Karla, também há menção do quanto é importante o religioso/missionário estar preparado para ajudar outras pessoas que estão precisando de restauração. Ela está se referindo à necessidade de as denominações religiosas acolherem os homossexuais, bissexuais, travestis e transexuais de modo aberto. Porém, ofertando cura para eles.

$\mathrm{Eu}$ gostaria que hoje a gente se desarmasse, porque às vezes a gente fala: eu quero ajudar o outro, eu quero vê o outro, eu quero evangelizar. Vamos olhar primeiro pra nossa sexualidade, porque a gente como igreja precisa pensar que a igreja precisa estar restaurada. Eu como corpo de cristo preciso tá curado pra ajudar quem tá entrando. A igreja é o lugar e ela deve ser o ambiente saudável em que as pessoas vêm pra serem restauradas, inclusive na área sexual e a gente precisa criar na igreja, na Gólgota, hoje, esse ambiente, um ambiente que as pessoas venham, que travestis, que homossexuais, que profissionais do sexo venham e sejam restaurados, que sintam esse clima de amor, de graça, de misericórdia. Amém? ${ }^{31}$ (Grifos meus).

Os discursos são importantes por pontuarem a necessidade das denominações religiosas e seus fiéis de mudarem a sua forma de pensar para que consigam, efetivamente, não apenas acolher, mas respeitar tais sujeitos na/em comunidade. É um conflito entre o amor ao próximo, princípio bíblico, bem como a postura de se abrir e acolher esse diferente. Aqui é evidente que o "venha como você é", porque o que importa para Deus é o seu coração, não se aplica a todas as situações, na Gólgota.

${ }^{31}$ Comunidade Gólgota. Disponível em: https://www.comunidade.golgota.org. Acesso em: 20 jan. 2018. Grifos meus. 
Religare, ISSN: 19826605, v.16, n.1, agosto de 2019, p.306-337.

No que se refere ao missionarismo com prostitutas e travestis, Karla no seminário "Sexo: santo ou profano?" cita exemplos dos missionários nas ruas curitibanas:

A gente conheceu uma travesti faz pouco tempo, a Renata, ela é profissional do sexo também, saiu do armário com 16 anos. É filha de pastor da igreja e caiu com outro pastor. Olha que lindo! Aí quando a gente tava conversando eu perguntei: mas e o pastor lá que você teve um caso, ele largou a mulher? Não, tá lá com a igreja, com a família, com a esposa. Que lindo, né? ${ }^{32}$

Aqui, há um indício interessante para a discussão e para a análise da transgressão, apesar da tônica do discurso. Não se trata apenas de lidar com um determinado público, pelo evangelismo e missionarismo para além dos templos. Questões atreladas às famílias de lideranças têm aparecido, ou seja, internamente igrejas e denominações religiosas também passaram a contar com questões que não são apenas do mundo, elas estão dentro das famílias, das casas, dos templos. Nesse sentido, a missionária critica moralmente, creditando como hipócrita a postura de um pastor, que se envolveu afetivamente com a travesti, praticando adultério e se mantendo líder religioso, pai de família e casado, questionando seu exemplo enquanto liderança devido à prática.

De modo geral, o conjunto dos exemplos demonstra que, embora se trate de uma comunidade pequena, verificam-se seus esforços para crescer. Se no momento de sua fundação, em 2001, eram 8 pessoas, no ano seguinte, conforme reportagem do Programa Bom Dia Brasil, da emissora Rede Globo, eram 34, quando situados na Rua Clotário Portugal, na capital paranaense. Em 2004, sendo transferida para o centro da cidade, na Avenida Visconde de Guarapuava, conforme apontamento do pastor Pipe, em entrevista para a produção do projeto de Tese, no ano de 2010, Gólgota contava com aproximadamente 160 adeptos. Seis anos depois, em 2010, de acordo com o líder do Ministério MotoClube, contava com cerca de 180 pessoas. Ao longo de seis anos, a comunidade recebeu,

32 Idem. 
Religare, ISSN: 19826605, v.16, n.1, agosto de 2019, p.306-337.

em números absolutos, somente 20 novos adeptos. E quatro anos depois, em 2014 havia, de acordo com o líder do Ministério Infantil, as mesmas 180 pessoas.

Levantamos duas hipóteses para o questionamento sobre o crescimento: o ingresso de adeptos é ínfimo, ou seja, o discurso dos líderes da Gólgota não consegue atrair novos adeptos ou, ainda, apesar de atrair novos adeptos, o discurso da Gólgota não é eficaz no sentido de manter os fiéis. Assim, apesar do esforço empreendido para arrebanhar fiéis, os números apresentados, a partir de 2004, apontam para o fracasso destas ações.

O que nos parece óbvio é que boa parte das tentativas não funcionaram. Ao contrário dos discursos de algumas lideranças de que a Gólgota não está preocupada com crescimentos numéricos, e sim constituir uma família de roqueiros protestantes, que envelhece na comunidade, não seria uma justificativa discursiva encontrada para não admitir que as estratégias para arrebanhar foram ineficazes? Ou melhor, ela parece ser mais eficaz na tentativa de pôr em prática seus dois primeiros pilares: a salvação e a graça, direcionada ao público-alvo, aos que podem vir a conhecer o templo e, talvez, frequentá-lo. No entanto, em se tratando do último pilar, a eternidade de Deus, ela não é bem sucedida, contando com apenas vinte novos membros fiéis, em cerca de seis anos. Vejamos agora, alguns exemplos dos que permaneceram em comunidade no intuito de refletir sobre as justificativas para a permanência, ao contrário do que discutimos até aqui.

\section{"O ambiente tem a minha personalidade, entendeu?": os que entram ficam!}

Optamos por trabalhar com duas narrativas de membros, utilizando codinomes, para exemplificar os que permaneceram em comunidade, apesar de não termos fonte para contraposição, os que deixaram a Gólgota. A primeira entrevista foi produzida em 27 de julho de 2010, com João, na época com 31 anos. A segunda, 16 de janeiro de 2014, com Mateus, na época com 33 anos. Ambas 
Religare, ISSN: 19826605, v.16, n.1, agosto de 2019, p.306-337.

servem como subsídio para debater a questão da identificação cultural enquanto elemento central. Aquele entrevistado é frequentador desde os primeiros anos de fundação, anos 2000, e este, frequentador desde o final da primeira década do século XXI. O primeiro tornou-se membro ao longo da primeira década do milênio, enquanto o outro, a partir da segunda década do século XX.

Ao refletirmos os critérios de ingresso (entrada) na denominação religiosa, encontramos menções do entrevistado João, sobre o porquê escolheu a Gólgota.

É o meu lugar, é um refugio cultural, não assim social no sentido de revolta, de rebeldia. Eu acho que algumas igrejas estão erradas, não concordo com algumas teologias que estão por aí, mas eu tô na Gólgota por uma questão cultural mesmo. O ambiente tem a minha personalidade, entendeu? (JÕ̃O, 2010).

Outros personagens advêm de diversas tradições religiosas pentecostais como é o caso de Mateus. Ao ser entrevistado, destacou sua trajetória religiosa, a origem familiar na Igreja Batista de Cascavel, Protestante Histórica, diferentemente de João, que possui origem familiar na Igreja do Evangelho Quadrangular, Pentecostal de segunda onda.

Fui criado desde criança num lar cristão. Quando eu tinha dois anos minha família se converteu ao evangelho. Minha família é bem matriarcal, vem da minha bisavó, que sempre teve o controle da família, e depois da conversão dela todos foram fazendo a conversão também (MATEUS, 2014).

A partir da caracterização do entrevistado em enfatizar a família por intermédio das figuras femininas, é interessante mencionar que, diferentemente de visualizarmos a mulher, em matrizes evangélicas como figura excluída e diferenciada do homem, inclusive com muitas lideranças utilizando passagens bíblicas para a justificativa do patriarcalismo religioso; este não é o caso do entrevistado.

Concomitantemente, após a consideração da origem religiosa, Mateus construiu sua narrativa, linear, pela adolescência e as diferentes experiências que constituíram tal momento da vida. Quando jovem, enquanto cursava graduação 
Religare, ISSN: 19826605, v.16, n.1, agosto de 2019, p.306-337.

universitária, saiu de casa e passou um tempo afastado da família e da denominação religiosa. Diferentemente de João, que não queria que os pais o vissem como um "desigrejado", Mateus assumiu tal postura:

Ainda quando eu estava na graduação, na cidade dos meus pais, encontrei um homem na rua que eu nunca tinha visto, ele me abordou, pediu um cigarro e disse: eu senti que Deus me mandou falar com você, Deus não tá feliz com a postura que você tá tendo, isso não tá legal! (MATEUS, 2014).

A narrativa é construída apontando para as tensões da sua experiência individual. Há um desejo corriqueiro de limpar-se, de regenerar a vida, permeado por um sentimento de culpa. Ele demonstra, principalmente nos momentos em que relatou estar "desigrejado", o quanto recebeu sinais de Deus para que retomasse a caminhada cristã. É importante pontuar aqui que, apesar de ter uma experiência religiosa, anteriormente à Gólgota, numa igreja protestante histórica, sua constante menção dos sinais enviados por Deus a ele, é uma característica maior do campo pentecostal evangélico e do próprio catolicismo.

A retomada do cristianismo pelo líder do ministério infantil foi admitida por ele após uma experiência traumática, quando recebeu uma revelação em forma de alerta sobre sua vida. Aliás, essa é uma constatação possível de ser observada em muitos relatos de conversão religiosa, de diferentes orientações, não apenas evangélicas, que giram em torno de experiências com a dor e a gratidão a Deus, assim como o desejo de consagrar-se a seu serviço, podendo constituir, inclusive, tarefas de ação missionária. Nas palavras de Mateus:

Finalizando a faculdade, eu me envolvi num acidente de carro; foi bem simples, nada grave, somente danos materiais. Quando eu já estava no mestrado, coincidentemente, quarenta e cinco dias depois, eu sofri um acidente mais grave, um capotamento, e quando o carro parou eu vi um anjo do meu lado que falou pra mim: essa é a última vez que eu tô com você! Da próxima vez você não escapa! Fiquei bem grilado. Conversei bastante com Deus pra entender o que tava acontecendo e foi onde eu decidi ter um relacionamento mais sério com ele (MATEUS, 2014). 
Religare, ISSN: 19826605, v.16, n.1, agosto de 2019, p.306-337.

O narrado pelo entrevistado apresenta um Deus que alerta, ao mesmo tempo em que pune, aproximando-se de muitas crenças do catolicismo, além de pertencente a expressões de senso comum: “Deus castiga”! Contudo, é preciso problematizar tal ideia. Para Mateus, o momento em que sentiu a necessidade de manter um relacionamento sério com Deus e retomar a sua vida cristã, também operação divina (esta é uma prerrogativa protestante), veio com a oportunidade de sua família sair da cidade de Cascavel, Oeste do Paraná, ingressando na capital do Estado, Curitiba. Ao chegarem, a família se realocou na mesma congregação, a Batista Renovada, que sempre frequentaram, mas o filho, sem identificação, resolveu procurar um espaço onde efetivamente se sentisse pertencente.

O outro entrevistado, João, que enfatizou muito a questão cultural como expressão de identificação, pertencimento e permanência na Gólgota, também mencionou como um dos motivos centrais para ter permanecido na comunidade, direcionando suas críticas a outras igrejas, especialmente as pertencentes ao Neopentecostalismo, que apostam na teologia da prosperidade. Em suas palavras: “Não esperemos outra coisa de Deus a não ser sermos o mais miserável dos homens!" (JOÃO, 2010).

O entrevistado constrói sua crítica ao Neopentecostalismo baseado em leituras do "Evangelho Puro e Simples", de C. S. Lewis, que é base de muitas pregações e cursos de formação ofertados pelo pastor Pipe, além de reivindicado por vários protestantes históricos. Esse é um aspecto que torna possível considerar a Gólgota com um pé no protestantismo histórico - talvez por herança da experiência religiosa própria de seu líder fundador, na Igreja Presbiteriana do Brasil. João contextualiza seu argumento:

A Igreja Evangélica, a nível de Brasil, ela passa hoje por uma crise terrível. Atualmente ela gira em torno de um mercado da fé. A teologia não é tratada enquanto teologia e as pessoas são guiadas por palavras sem contexto algum. Elas não são guiadas pra espiritualidade, é pregado aquilo que elas querem ouvir: Se eu tô 
Religare, ISSN: 19826605, v.16, n.1, agosto de 2019, p.306-337.

passando fome eu vou lá porque eu quero ser rico. A teologia é essa e Deus é colocado na parede, ele virou um garçom, quando na verdade nós deveríamos apenas prestar louvor a ele, entregar nossa vida diretamente a ele e mantermos uma relação direta com ele. Só que o que vem sendo pregado por essa teologia da prosperidade, essa teologia triunfalista é o contrário disso. Se a busca por conforto é o que é recomendável para um cristão, por que nós estamos comendo menos do cristianismo? Às vezes, por vontade de Deus, você tem que estar inclusive disposto a perder tudo, como aqueles que reformaram a teologia seguindo o cristianismo autêntico da igreja primitiva e foram mortos, perseguidos. Hoje não é diferente, tá entendendo? Então em termos de Gólgota, ela é uma das poucas igrejas com teologia cristã coerente. Eu tô falando isso com tristeza, com vergonha, não é porque eu tô exaltando a Gólgota, muito pelo contrário. É uma das poucas igrejas que mantém uma teologia coerente e um contexto histórico e cultural, sem precisar forçar passagem para atrair pessoas. Se tiver mil ou cem pessoas ali dentro a teologia que o Pipe vai estar passando é a mesma. Ele não vai se vender a um cara que tem convicção teológica distorcendo a bíblia que nem hoje em dia é feito. É uma coisa muito barata, fraca de conteúdo e é por isso que a gente tá vendo uma espiritualidade frustrada, fraca de conteúdo. O cara vai pra dentro da igreja com o objetivo de: ah eu tô desempregado, mas eu vou fazer uma campanha dentro da igreja e eu vou me tornar empresário. Tá, mas e se Deus não te ajudar a virar um empresário você vai ficar dentro do Reino? (JOÃO, 2010).

Em sua narrativa, ele faz uma crítica motivada pelos acontecimentos que envolveram grupos sociais e aparições midiáticas, principalmente nos anos 2000, em torno do crescimento e movimentações religiosas neopentecostais, como a Igreja Universal do Reino de Deus. Analisando sua fala, pode-se inferir que a crise citada é porque as lideranças religiosas, em nome da teologia da prosperidade, acabaram atraindo fiéis de forma manipulatória.

O entrevistado Mateus também aposta na crítica a outras denominações religiosas, especialmente as neopentecostais. Entretanto, ele pauta seu argumento a partir de um raciocínio sobre pessoas que costumam criticar a manipulação existente em algumas igrejas evangélicas, enfatizando que muitos “caem na conversa delas". Ele admitiu que a Gólgota é diferente de outras igrejas 
Religare, ISSN: 19826605, v.16, n.1, agosto de 2019, p.306-337.

evangélicas, porque o pastor fala pela graça e não pela lei, como fazem muitos líderes religiosos. Em suas palavras:

Por que as pessoas falam que não caem na conversa de uma igreja? É que esse tipo de igreja, de conceito, não prega pela graça igual a Gólgota, prega pela Lei! Então é que ninguém deve cair na conversa e no discurso. Cara, tipo assim, eu tô te trazendo o amor! Você quer amor? Então vem pra Gólgota! (MATEUS, 2014).

O que diz respeito à lei e a graça, nos dizeres do entrevistado, é uma construção bastante difundida entre os protestantes históricos, aliás referenciada com frequência pelo líder da Gólgota, ancorando-se nas reflexões do pastor Caio Fábio $^{33}$. Também representa o momento em que passou de frequentador e adepto, para membro, afinal, ele já havia aceitado a doutrina, seguido os três pilares golgotanos.

Outro ponto para discussão entre os dois entrevistados é a relação familiar no que se refere à participação na Gólgota. João diz ter frequentado, ao mesmo tempo, a Igreja do Evangelho Quadrangular (da família) e a Gólgota (por identificação). No quesito familiar, o entrevistado revela que não queria desapontar os pais e nem causar conflitos com eles, tendo de explicar que não se tornaria um "desigrejado" por não se identificar com a religião familiar: "Essas questões eu discuto na terapia, porque seria mais um problema com meus pais" (JÕ̃O, 2010).

\footnotetext{
${ }^{33}$ Caio Fábio é uma figura religiosa muito polêmica no cenário cristão brasileiro e internacional. Ordenou-se pastor, inicialmente na Igreja Presbiteriana do Brasil. Muitos o consideram o Billy Graham brasileiro devido à criação do VINDE (Visão Nacional de Evangelização), que o levou a realizar inúmeras cruzadas evangelísticas por todo o Brasil e a edificar um dos maiores complexos assistenciais da América Latina a "Fábrica de Esperança". Seu testamento e tema central sempre foi "Jesus". Atualmente tem um Ministério no YouTube e lidera um movimento chamado "Caminho da Graça", definido por muitos como a principal expressão do que é uma igreja emergente ou alternativa; escreveu vários livros, recomendados por protestantes históricos e, na mesma proporção, criticado por pentecostais como o psicólogo e pastor Silas Malafaia. Um colunista da Revista O Ultimato diz ser possível descrever a vida de Caio Fábio em três Caios, tendo em vista sua polêmica e movimentada vida. 1) pregador e líder cristão notável; 2) servo arrependido e disposto a recomeçar; 3) o líder alternativo de hoje. (Afinal quem é Caio Fábio? Disponível em: http://www.ultimato.com.br/comunidade-conteudo/afinal-quem-e-caio-fabio. Acesso em: 27 jul. 2015).
} 
Religare, ISSN: 19826605, v.16, n.1, agosto de 2019, p.306-337.

O entrevistado Mateus, ao invés de demonstrar uma preocupação maior com a família no sentido pais e irmãos, preocupa-se mais em "constituir a sua família" (mulher e filhos). No momento em que ele tocava no assunto, tive a impressão de que aparentava estar um pouco deprimido e, perguntei, se ele não estava deixando a sua vida amorosa de lado. Ele respondeu:

A minha vida amorosa não anda. Falando do ponto sexualmente, não tenho vida amorosa. Eu sinto falta, lógico. De vez em quando eu queria dar um beijo em alguém! Tenho vontade de sair. Só que com o tempo você acaba achando outra coisa pra fazer. Você troca de repente a vontade de beijar por uma festa com o pessoal da igreja, e você consegue desviar o foco. Não é uma coisa pesada pra mim, só que eu fico pensando, eu queria ter um relacionamento sério com alguém, casar e ter filhos! Só que será que alguma mulher, hoje, aceitaria o meu passado? (MATEUS, 2014).

Ao se remeter a questões de problemas familiares, aspectos sociais, a fala de Mateus permite pressupormos que, ao passar por crises, ele acredita na confissão como forma de obter ajuda, apresentando sentimento de "medo" que as pessoas fiquem sabendo sobre sua vida anteriormente à conversão ${ }^{34}$.

A questão dos trânsitos religiosos, a busca por um local de pertença, também permeia as duas entrevistas. Tal experiência marcou a vida de muitos fiéis evangélicos, principalmente entre os anos de 1980 e 1990, também atualmente. Para os entrevistados, após conhecerem a comunidade, percorrendo inúmeros locais sem identificação, a Gólgota, além de oferecer uma questão identitária para sua membresia, apresenta formas para que o jovem amadureça no cristianismo. Por ser uma denominação religiosa pequena, preocupada com a teologia cristã e o desenvolvimento espiritual de seus fiéis, consegue treinar o cristão para a maturidade, pregando a Salvação, a Graça e a Eternidade de Deus

\footnotetext{
34 São exemplos: Amigos que conduzem à cura. Disponível em: https://www.youtube.com/watch?v=G7xoCDj_dYc. Acesso em: 20 de jun. 2018; A Bíblia e o divórcio. Disponível em: https://www.youtube.com/watch?v=o-66c5MYV9Q. Acesso em: 20 de jun. 2018; A Praxis do Amor. Disponível em: https://www.youtube.com/watch?v=2a37a8bv0ho). Acesso em: 20 de jun. 2018; Pai Presente. Disponível em: https://www.youtube.com/watch?v=3QL42Perot4. Acesso em: 20 de jun. 2018.
} 
Religare, ISSN: 19826605, v.16, n.1, agosto de 2019, p.306-337.

como passo a passo do amadurecimento (a passagem da juventude para a vida adulta).

A teologia cristã do amadurecimento, defendida pela Gólgota, despreza a teoria materialista de mundo no sentido de que o fiel deve trabalhar, juntar dinheiro, obter, investir em coisas materiais, pois não é o que Deus espera dele. O princípio é pegar a cruz e seguir, "ser o mais miserável dos homens", como admitiu o entrevistado João. Uma vez que igrejas e denominações religiosas direcionaram-se apenas às lideranças juvenis, ao longo dos anos, foi possível observar, no campo evangélico, uma alteração de práticas referentes não apenas a tal público, que também sempre foi historicamente mirado por diferentes religiões.

No início, a Gólgota investia em linguagem adequada ao público, não que isto não continue ocorrendo, mas muitos membros foram envelhecendo permanentes nos templos, do mesmo modo que suas lideranças. Assim, muitas delas passaram a investir na ideia de maturidade; algumas nem chegam a mencionar maturidade cristã, como faz a Gólgota, mas que os jovens fazem questão de mencionar que são direcionadas a eles.

Outro aspecto relevante é a constatação de que, independente da religião frequentada, o que importa para a família parece ser a de que o filho golgotano pertença. Afinal, fazer parte de uma congregação pode sugerir que o mesmo esteja salvo, além de possivelmente estar mais próximo da família, por conta dos valores cristãos. É outra evidência da realização do terceiro pilar golgotano: a eternidade de Deus, inclusive, com aval familiar. Após a doutrina ter sido introjetada no frequentador/adepto, ele se torna membro efetivo, pertencente à comunidade, comungando das premissas religiosas.

A Gólgota, vista como reabilitadora e com formatos de culto nãohabituais, além do estilo/estética de lideranças e membresia, pode assustar famílias mais tradicionais. Pipe denomina o processo como um choque cultural (o primeiro passo para a aceitação familiar). Mateus, nesse sentido, vindo de uma 
Religare, ISSN: 19826605, v.16, n.1, agosto de 2019, p.306-337.

família matriarcal, onde as mulheres constituem a força dominante, num espaço onde todos moram na mesma casa, com convívio profícuo, parece ter levado a mãe a uma preocupação maior. Ela procurou conhecer o funcionamento da Gólgota, por exemplo, sem contar para o filho.

\section{Considerações finais}

Considerar a denominação religiosa como reabilitadora e inclusiva para os excluídos culturais é o que evidencia a principal estratégia da comunidade em manter e ofertar expressões culturais aos seus membros. A utilização, durante o culto, do rock, parece aproximar e trazer para o convívio dos cristãos as pessoas marginalizadas, também por estigmas sociais apregoados, em virtude da representação dos estilos de vida de um possível roqueiro. Nessa direção, as igrejas emergentes parecem tentar uma quebra de paradigmas, seja diante da juventude que pode extrapolar experiências geracionais, principalmente dos mais velhos, seja diante da efemeridade das relações diante de uma modernidade líquida, seja ainda diante da incorporação de ferramentas midiáticas, também efêmeras e líquidas, que nem sempre surte o efeito desejado pelas lideranças.

A utilização da música como forma de cultuar, de trazer para a comunidade grupos que se identificam com essa maneira de evangelização, evidencia-se nos discursos de João e de Mateus. Ambos referem-se à importância da música para a membresia. Tal discussão remete à ideia da exclusão ou da inclusão através do estilo escolhido, da estética apresentada pelo grupo e, também, individualmente. Como sentir-se parte em uma sociedade onde padrões tão diferentes são utilizados de formas tão desiguais? Apesar da acolhida para os roqueiros dentro da comunidade, os entrevistados em sua maioria fizeram questão de frisar que seu estilo/estética é um dos pontos em que sofrem preconceito por parte da sociedade curitibana. Por isso, buscam espaços de pertença (socialidade e sociabilidade), especialmente aqueles que os desvinculam 
Religare, ISSN: 19826605, v.16, n.1, agosto de 2019, p.306-337.

de imaginários e julgamentos como os e que são agressivos, dependentes químicos, satanistas.

É por aí que caminha a questão da junção, efetuada pela Gólgota, entre o sagrado e o profano - pelo aspecto missionário e não apenas de estilo de culto. Há o relato de que os fiéis tem um chamado e devem desempenhar a missão onde quer que estejam. Por outro lado, vários integrantes revelaram a luta diária, na sociedade, por conta do cristão convertido "assumir-se como um evangélico", apesar de seu estilo/estética que poderiam fazer com que passassem despercebidos no sentido da conversão religiosa.

É válido mencionar que abordamos apenas algumas expressões, a partir da trajetória religiosa e de vida de dois membros da Gólgota, como exemplos de identificações que surgiram no efeito de manter a membresia na denominação religiosa. No entanto, também oferecemos indicativos das experiências que parecem não ter surtido efeito dentro da comunidade. A novidade golgotana parece estar muito mais na aparência estilo/estética, porque apresenta uma imagem libertária, questionadora, mas que na prática faz uso de premissas tradicionais cristãs ocidentais. Não estamos dizendo que suas lideranças não apontaram para isso desde o início. No entanto, a empreitada nos parece conservadora. Daí o motivo para uma atração de público por intermédio de expressões culturais, mas de uma não ampliação diante de concepções e práticas.

Também é possível considerar a Gólgota como uma denominação religiosa evangélica intermediária. Não está nem inteiramente ligada aos mais tradicionais do campo, nem tampouco aos inclusivos, que reivindicam para si o direito de expressão da grande novidade do terreno evangélico, nos últimos anos. A Gólgota, no geral, não parece sequer pertencente às igrejas emergentes evangélicas, das quais teve origem, na virada do século XXI.

A comunidade adaptou o discurso ao longo dos anos, fazendo uso do radicalismo punk, underground em seus dogmas, apesar de manter o estilo/estética do movimento. Nesse sentido, atingir um público mais juvenil e underground não 
Religare, ISSN: 19826605, v.16, n.1, agosto de 2019, p.306-337.

foi mais sinônimo de emergente, a partir de 2015. Pelo contrário, tornou-se sinônimo de crítica ao campo, por parte das lideranças, considerando o fenômeno muito fluído e, por conta disso, relativizador. Ser homossexual, realizar um aborto, adotar uma postura política comunista, entre outros, passaram a ser vistos como aceitação oferecida pela própria pós-modernidade e, por isso, não aceitos em comunidade, embora o Cristo e o Deus que se pregue sejam amorosos, não preguem distinções, nem façam acepções entre pessoas.

\section{Referências}

BAUMAN, Zygmunt. Modernidade líquida. Tradução Plínio Dentzien. Rio de janeiro: Zahar, 1999.

Comunidade: a busca por segurança no mundo atual. Tradução Plínio Dentzien. Rio de Janeiro: Zahar, 2003.

Identidade. Tradução Carlos Alberto Medeiros. Rio de Janeiro: Zahar, 2005. BRANCO, Patrícia Villar. O metal cristão: música, religiosidade e performance. Dissertação (Mestrado em Antropologia Social) - Universidade Federal do Paraná, Curitiba, 2011.

CANDAU, Joel. Memória e identidade. São Paulo: Contexto, 2011.

CARDOSO, Diogo da Silva. O rock e o metal a serviço de Deus: o lugar e os territórios do movimento underground cristão brasileiro. Anais do III encontro de geografia. Goyacazes-RJ: Instituto Federal Fluminense, 2010.

CATANI, Afrânio Mendes; GILIALI, Renato de Souza Porto. Culturas juvenis: múltiplos olhares. São Paulo: Ed. UNESP, 2008.

CERTEAU, Michel de. A Invenção do cotidiano - Artes do Fazer. Petrópolis: Vozes, 1998.

CUNHA, Magali do Nascimento. Vinho novo em odres velhos: um olhar comunicacional sobre a explosão gospel no cenário religioso evangélico. Tese (Doutorado em Ciências da Comunicação) - Universidade de São Paulo, São Paulo, 2004.

FERREIRA, Laís Cândida. Geração que canta: as faces do rock na cultura evangélica juvenil brasileira (1990-2010). Trabalho de Conclusão Curso (História) - Universidade Federal do Paraná, Curitiba, 2013.

HOOVER, Stewart M. Religion in the media age. Routledge, 2006.

JENKIN, Henry. Cultura da convergência. São Paulo: Aleph, 2006.

MARANHÃO FILHO, Eduardo Meinberg de Albuquerque. A grande onda vai te pegar: mídia, mercado e espetáculo da fé na Bola de Neve Church. Florianópolis: UDESC, 2013.

MASCHIO, Maralice. O movimento underground e a religiosidade: Comunidade Gólgota (2001-2015). Tese (Doutorado em História) - Universidade Federal do Paraná, Curitiba, 2018.

NOLETO, Rafael da Silva. Religião e sexualidade: dilemas contemporâneos brasileiros. Cadernos Pagu, Campinas, n. 46, jan.-abr. 2016.

ROMEIRO, Paulo. Decepcionados com a graça: esperanças e frustrações no Brasil neopentecostal. São Paulo: Mundo Cristão, 2005.

\section{Fontes}


Entrevista concedida por Marcos, codinome, em 27 jul. 2010. Acervo da pesquisadora. Entrevista concedida por João, codinome, em 27 jul. 2010. Acervo da pesquisadora. Entrevista concedida por Lucas, codinome, em 27 jul. 2010. Acervo da pesquisadora. Entrevista concedida por Volmir de Bastos, pastor, em 05 ago. 2010. Acervo da pesquisadora.

Entrevista concedida por Mateus, codinome, em 16 jan. 2014. Acervo da pesquisadora. URL: Comunidade Gólgota. Disponível em: http://comunidade.golgota.org/. Acesso digitalizado pela pesquisadora entre 2001 (criação do Site) e 2015 (término da pesquisa). URL: Descontradizendo Contradições. Disponível em: http://www.dc.golgota.org/. Acesso digitalizado pela pesquisadora 2015 (término da pesquisa).

URL: Comunidade Gólgota: ministérios MetalCast. Disponível em: http://comunidade.golgota.org/ministerios/metalcast/. Acesso digitalizado pela pesquisadora entre 2008 (criação do portal Metalcast) e 2015 (término da pesquisa).

URL: Facebook: Comunidade Gólgota. Disponível em: https://www.facebook.com/comunidade.golgota. Acesso digitalizado pela pesquisadora entre 2011 (criação da Página do Facebook) e 2015 (término da pesquisa).

URL: Facebook: Descontradizendo Contradições. Disponível em: https://www.facebook.com/descontradizendocontradicoes/. Acesso digitalizado pela pesquisadora entre 2012 (criação da Página no Facebook) e 2015 (término da pesquisa).

Recebido em 15-10-2018.

Aprovado em 04-10-2019. 